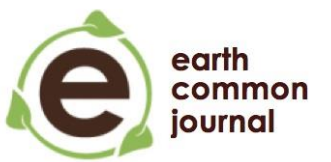

Earth Common Journal

Synthesis_-Uniting Health, Nutrition, and Earth

MacEwan University

Volume 7, Number 1, October 2017

\title{
Article
}

\section{Inuit Co-Management Strategies in the Arctic}

Emily Villanueva*

\begin{abstract}
Inuit co-management of northern resources and environments is critical to the survival of these rapidly changing ecosystems. This paper explores comanagement initiatives currently present in the Arctic, including the creation and implementation of these strategies. The relationship between Indigenous traditional knowledge and the success of co-management strategies is analyzed, noting that dismissive beliefs held by Eurocentric power figures affect the existence and enforcement of these strategies. This paper concludes that the effects of climate change and faunal conservation are two of the pillars upon which successful co-management techniques are founded in Arctic communities, making them key players in the pursuit of a sustainable future.
\end{abstract}




\section{Inuit Co-Management Strategies in the Arctic}

\section{Introduction}

Wildlife management in the Canadian North is an area that has been experiencing extensive attention in the face of recent and rapid environmental changes. By examining the roles of local and traditional ecological knowledge in the creation and implementation of wildlife co-management practices, a greater understanding of Indigenous knowledge and its collaborative properties can be reached. This paper will focus on the Inuit of northern Canada and Greenland, and the application of Indigenous ways of knowing in both small-scale and large-scale co-management settings. A critical approach will be employed in evaluating current Arctic co-management practices, and the factors that influence these practices will be further explored through a broad examination of management strategies in northern coastal regions and the application of these strategies in specific faunal cases.

The role of power is one that cannot be ignored when analyzing co-management practices. In these instances, power becomes a wholly transformative entity capable of both the creation and destruction of Indigenous opportunity. Power is intrinsically entangled with politics, and government bodies have dominance over the Inuit people. The incorporation or exclusion of Indigenous knowledge in government policy is a conscious choice, and one that demonstrates how this knowledge is viewed by Eurosettler governments. These choices are often rooted in colonial ideologies that perpetuate racism, ethnocentrism, and Western government systems, and traditional ecological knowledge is thus viewed with disdain. It is impossible to separate traditional knowledge from its source, and the dismissal that stems from colonial ideologies is a prejudicial act of racism in which the neo-colonialist settler mentality disallows nonWestern forms of science or ways of thinking from achieving legitimacy. Trivializing important aspects of Inuit knowledge delegitimizes them and enforces narrow Eurocentric views of the "civilized West" and the "primitive other."

\section{Environmental Resource Management}

Berkes, Berkes and Fast's (2007) article, “Collaborative Integrated Management in Canada's North: The Role of Local and Traditional Knowledge and CommunityBased Monitoring," is a look into the application of integrated management techniques in Canada's northern coastal regions. The roles of local and traditional ecological knowledge, as well as community-based monitoring practices, are examined within the context of ecological management (p. 143). There are three primary factors that make 
northern Canada a receptive environment for integrated management techniques. First, coastal zone management in the Canadian Arctic lacks the complexity found in other regions of the world, due to the simplicity of the Canadian North in comparison to other coastlines where various issues disrupt attempts at sustainable collaboration (p. 145). Following this, Berkes et al. point out the rapidly growing conditions of change in the Arctic, both social and environmental, as another contributing factor (p. 145). Finally, Canadian Aboriginal land claim agreements have led to the establishment of governmental regimes that are ideally amenable to collaboration and co-management processes (p. 145). This is due to the transparency and ease with which these processes have been implemented, with coastal areas spanning the entire country being protected by such land claim agreements (p. 145). As well, participatory decision-making processes have been evolving since the 1970s, leading to greater involvement of Indigenous people in government collaboration (Bp. 145).

The article is separated into three sections that further explain how these management techniques work. The first section explored by Berkes et al. (2007) is the case of the Beaufort Sea, a designated Large Ocean Management Area where a consultative planning process is employed among Indigenous communities as well as other stakeholders in order to build a relationship of trust and open communication ( $\mathrm{p}$. 147). The second section is in relation to traditional ecological knowledge as a means of analyzing marine contamination in the Arctic, with traditional ecological knowledge gaining favour in the West for being a flexible set of indicators that are modifiable with changing conditions (p. 154). The final section examines the contribution of Indigenous knowledge to the monitoring of environmental change, as the Inuit measure weather patterns in a fundamentally different way than Western scientists do (p. 157). While Western science examines average changes, the Inuit examine frequency and magnitude, including the occurrence of extreme weather events, and the predictability of weather patterns (p. 157).

In Manseau, Parlee, and Ayles' (2005) chapter, “A Place for Traditional Ecological Knowledge in Resource Management," a broader and more all-encompassing view of traditional ecological knowledge is looked at (pp. 141-164). The authors focus on the increase in the use of traditional ecological knowledge in decision-making in northern Canada, an increase likely due to the active involvement of Indigenous groups, governmental and non-governmental organizations, and academics (p. 142). There are three primary questions that Manseau et al. are hoping to answer in regards to the contribution of traditional ecological knowledge to northern resource management: the role of government in ensuring the use of traditional ecological knowledge in resource 
management, the role of management institutions in facilitating the inclusion of traditional ecological knowledge in decision-making, and the role of the community in capturing and transforming traditional ecological knowledge and applying it to resource management (p. 142).

While government agreements, such as the Nunavut Land Claims Agreement and the Inuit Impact and Benefit agreement, and management agencies, such as the Environmental Monitoring Advisory Board, hold more power than community factions and have resulted in more immediate implementations of traditional ecological knowledge, it is clear that local communities have been at the forefront of many of these initiatives and are indispensable proponents of this movement (p. 144). To illustrate this point, the authors first study the Fisheries Joint Management Committee of the Inuvialuit settlement region, which provides information about the use of traditional ecological knowledge in fisheries and marine management, followed by the Lutsel K'e initiative in the Northwest Territories, which records and uses traditional knowledge in response to concerns regarding mining and development (pp. 143-150). The final initiative examined is from Nunavut's Quttinirpaaq National Park which, in collaboration with the Nunavut Land Claims Agreement and the Inuit Impact and Benefit Agreement, incorporates the government and community in collaborative management and traditional ecological knowledge regarding park management (pp. 151152).

An issue that often arises regarding resource management is a lack of opportunities for community involvement or the sharing of traditional knowledge, which discourages and alienates the community. Some Arctic communities are now taking back ownership of their traditional knowledge by using it in resource management capacities to alter marine health indicators, and by controlling the collection, analysis, and interpretation of scientific data (Manseau et al., 2005, p. 143). While this transformation of knowledge may be welcomed by most within the community, making a space for it in external contexts is still a potential issue. Adamant opponents of the implementation of traditional knowledge will remain against it regardless of how palatable it is made for a Western audience, and those opposed are often in positions of power and dominance. Manseau et al.'s chapter demonstrates how co-management between locals and government bodies can create a forum for sharing and combining scientific and traditional knowledge in a way that benefits all those involved (p. 160). 


\section{Faunal Management in the Arctic}

Nielsen and Meilby's (2013) article, "Quotas on Narwhal ("Monodon monoceros") Hunting in East Greenland: Trends in Narwhal Killed per Hunter and Potential Impacts of Regulations on Inuit Communities," examines how sanctions and quotas placed on narwhal hunting have negatively affected Inuit culture. Narwhal migration patterns are looked at, as well as the number of narwhals killed per hunter, with assessments done via group comparisons between eastern and northwestern Greenland (p. 187). Although quotas were intended to increase the local narwhal population, a mass migration of nonhunted narwhal populations to the southwest has been recorded, an unexpected result of short-sighted quotas that failed to account for narwhal migration patterns and actually decreased the overall narwhal population in East Greenland (p. 200).

Ultimately, Nielsen and Meilby (2013) draw three conclusions from their study: quotas and regulations result in negative consequences for Inuit communities, East Greenland did not see a negative trend in the narwhal populations that were hunted, and immigration of non-hunted narwhal populations is possible when quotas are imposed ( $\mathrm{p}$. 200). In addition to this, a decline in ice cover was noted, demonstrating possible effects of climate change in the Arctic (p. 198). It is argued that co-management agreements, decentralization of management, and the inclusion and participation of local populations will aid in the eventual sustainable use and conservation of narwhals (p. 200). The lack of incorporation of local and traditional ecological knowledge in setting quotas is evident in this article, and Nielsen and Meilby cite this as an inappropriate implementation of power that demonstrates the persistent racism and marginalization of the Inuit, and the single-minded Eurocentric point of view that leads to uninformed and irresponsible uses of power (p. 201). Cultural absolutism once again prevails, and few, if any, attempts are made by the colonialists to understand or protect Indigenous cultural practices.

This trend towards anti-whaling tendencies is problematic, and does not bode well for the Inuit. Repercussions of anti-whaling movements can be seen in Norway, where whale tourism has become an act of anti-whaling resistance (Ris, 1993, p. 156). Foreigners and entrepreneurs have created recreational whale tourism as an affront to traditional whaling communities, in the hopes that they will be able to change whalers and locals' perceptions about whales (p. 158). These have not proven successful, as whaling is a deeply ingrained aspect of northern communities, and this Anglo-American attempt to decontextualize the critical role of whaling and other subsistence activities in northern communities has the potential to destroy northern economies and permanently affect Indigenous ways of life (p. 162). 
"Sentient Beings and Wildlife Resources: Inuit, Beluga Whales and Management Regimes in the Canadian Arctic," by Tyrrell (2007), examines beluga whale hunting and management in northern Canada. Beluga whale hunting is one of the most important subsistence activities in the Canadian Arctic, allowing for the affirmation of social identity and relationships in Inuit communities (p. 575). The belief that whales and humans exist in a shared social space is central to the Inuit belief system; however, western wildlife managers have been imposing management plans and quotas on beluga whale hunting, viewing these whales as a scarce resource in need of protection (p. 577). At the time Tyrrell's article was published, there were no whale management plans on the west coast of Hudson Bay, but in 2002, the Inuit of Nunavut sold part of their harvest to the Inuit of northern Quebec, an area burdened by hunting quotas (p. 575). The proximity of the Nunavut Inuit to these sanctions has led to fear and vulnerability in northern Inuit communities, where the future of their autonomy is being threatened by government regulations (p. 584).

Tyrrell (2007), however, states that the creation of the Nunavut Wildlife Management Board is a step in the right direction, incorporating both Western scientific research, and Inuit traditional ecological knowledge to protect the beluga whale (p. 582). The Nunavut Wildlife Management Board is a co-management board established as a result of the Nunavut Land Claims Agreement (p. 576). Its goal is incorporating local and traditional ecological knowledge and Western science into wildlife conservation by using the expertise of elders, biologists, and resource users (p. 576). This acquired knowledge is then used to determine harvest limits, parameters of wildlife research, and methods for promoting ecosystem integrity (p. 576). The Board is committed to the protection and promotion of Inuit ideologies, and for this reason most Inuit are in favour of it, although Tyrrell notes that some are concerned about the distinction made between the natural world and the human world in management plans, which does not align with traditional Inuit beliefs (p. 585).

In Schmidt and Dowsley's (2010) article, "Hunting with Polar Bears: Problems with the Passive Properties of the Commons," the quota approach is examined once more. The Inuit view their prey, the polar bears, as actively involved in the hunt, with both the hunter and the hunted being willing participants (Fienup-Riordan, 1990, Chapter 8, p. 138). Although Inuit hunters believe that humans and animals exist in a careful symbiosis, based upon need and respect, this viewpoint does not align with the predominant Western viewpoint, causing conflict (Schmidt \& Dowsley, 2010, p. 377). Western wildlife management systems tend to view the natural world as a passive entity, incapable of active participation in a human-centric world (p. 377). Schmidt and 
Dowsley cite this as a problem, as it directly contradicts the Inuit belief in active and participatory animals and environments (p. 378). An emphasis is placed on Arctic Canada, particularly Nunavut, as Nunavut employs a collaborative and highly advanced co-management system in which a flexible quota is enforced (p. 384). This allows for traditional Inuit-polar bear hunting, but is not counterproductive to conservation efforts. Schmidt and Dowsley's article demonstrates that common-pool resources can be sustainably managed without assuming the passivity of their existence, and two suggestions are made to improve the current issues at hand: paying closer attention to the empirical work on common-pool resource systems, and a reconsideration of theories of common-pool resources (p. 385).

The concept of common property versus open access property is also central to the understanding of resource conservation and management in the Arctic, as they are two fundamentally different concepts that are often falsely equated with one another. Common, or communal property is property in which an identifiable group has access and management rights, whereas open access refers to an area in which a resource is accessible to all users, regardless of affiliation (Berkes, 2012, p. 238). Common property and common-pool resource systems that respect indigenous beliefs would propel traditional subsistence activities within Inuit territories, and Schmidt and Dowsley (2010) state that the current systems must be modified to stop the one-sided relationship that occurs between a hunter and their prey when the prey has been assigned through a Western quota system (p. 382).

In Wenzel's (2010) article, "Polar Bear Management, Sport Hunting and Inuit Subsistence at Clyde River, Nunavut," the evolution of polar bear management in Canada is looked at, with an emphasis placed on Nunavut management practices (p. 457). Polar bear management techniques began with the creation of the Agreement on the Conservation of Polar Bears in 1973 (Wenzel, 2010, p. 457). Wenzel's article focuses on the successes of the agreement and how Inuit subsistence practices are supported in Nunavut, taking into account the importance of polar bears in Inuit communities, both economically and culturally. Wenzel places a particular focus on the economic advantages and uses of polar bears in Inuit subsistence, as well as in sport hunting, and points out that although hunting for sport is markedly different than hunting for subsistence, the wages earned from sport hunting allow for the continuation of subsistence hunting, and thus serve as a way for the Inuit to invest themselves in their own economy (p. 462). Sport hunting falls within the Agreement on the Conservation of Polar Bear's provisions as an aid to the economically disadvantaged Inuit, by allowing 
the sale of bear hides by individuals, as well as permitting non-Inuit hunting within the quota system (p. 464).

Wenzel (2010) demonstrates how polar bears, sport hunting, and Inuit subsistence strategies fit together seamlessly to create one of the most efficient, innovative, and collaborative wildlife management systems in Canada (p. 464). However, these systems exist in a time of uncertainty, as the impacts of climate change continue to negatively impact Arctic animals and their ecosystems. Polar bears have become both famous and infamous, as simultaneous icons and beacons of warning against the dangers of global warming (p. 457). This has led to questions about international polar bear management efforts, and whether Indigenous people should have the right to hunt polar bears when they appear to be on the precipice of disaster (p. 457). Particular criticism is placed upon the practice of sport hunting, seen by many as the co-opting of traditional Inuit practices by rich Qallunaat (i.e. the Inuktitut word for white people), a view that ignores the substantial financial contribution this practice has on both the Nunavut Economy and Inuit subsistence practices (p. 464).

\section{Conclusion}

These sources are meant to provide a fuller picture of some of the uses and implementations of co-management practices in northern Canada. By looking at small case studies, like that of the narwhal, and large management plans, like coastal and marine zone management, it becomes easy to see the importance of collaboration between Indigenous peoples and western entities (Berkes et al., 2007, ; Nielsen \& Meilby, 2013). Local and traditional ecological knowledge are necessary to gain a true understanding of the Canadian Arctic, and these articles demonstrate the negative repercussions that Indigenous exclusion from governmental and environmental planning has on Arctic ecosystems. They also explore the roles that power, colonialism, and politics play in Inuit co-management and perceptions of Indigenous knowledge. The article authors all emphasize the importance of context, and while simplification of the richness of traditional ecological knowledge is inevitable when consumed by nonIndigenous audiences, Arctic co-management boards are a step towards authentic and contextually accurate implementations of Indigenous knowledge. The involvement of Indigenous people in conservation efforts is critical to the success of resource management and conservation. To overlook the wisdom of the people who live on the land and who will be most greatly affected by its changes is an irresponsible and discriminatory act, and one that will prove detrimental to all in the end. 
* Author: Emily Villanueva is in her final year as an anthropology major and psychology minor in MacEwan University's Bachelor of Arts program. She spent this past summer excavating in Mill Creek Ravine with MacEwan's archaeology field school, an experience that was both exhausting and exbilarating. She would like to thank anthropology professor Dr. Franca Boag for encouraging her to submit this paper to Earth Common Journal.

\section{References}

Ashenmiller, Bevin. Cash Recycling, Waste Disposal Costs, and the Incomes of the Working Poor: Evidence from California, Land Economics, Vol. 85, No. 3 (Aug. 2009), 539-551.

Dewees, Donald N. and Hare, Michael J. Economic Analysis of Packaging W aste Reduction, Canadian Public Policy / Analyse de Politiques, Vol. 24, No. 4 (Dec., 1998), 453-470.

Farina, Blaise. A Portrait of World Historical Production and World Historical Waste after 1945, Review (Fernand Braudel Center), Vol. 30, No. 3 (2007), 177-213.

Gray, Murray J. Environment, Policy and Municipal Waste Management in the UK, Transactions of the Institute of British Geographers, Vol. 22, No. 1 (1997), 69-90.

Lindenlauf, Astrid. The Sea as a Place of No Return in Ancient Greece, World Archaeology, Vol. 35 No. 3, Seascapes, Dec 2003, 416-433.

Mervis, Jeffrey. Working with W aste: World of Waste, Science Magazine, Vol. 337, August 2012, 664-667.

Mervis, Jeffrey. Garbology 101: Getting a Grip on Waste, Science Magazine, Vol. 337, August 2012, 668-672.

Plambeck, Erica and Wang, Qiong. Effects of E-W aste Regulation on New Product Introduction, Management Science, Vol. 55, No. 3 (Mar. 2009), 333-347.

Prothero, Andrea, Dobscha, Susan, Freund, Jim et al. Sustainable Consumption: Opportunities for Consumer Research and Public Policy, American Marketing Association, Journal of Public Policy \& Marketing, Vol. 30 (1) Spring 2011, 31-38. 
Rathje, William L. The Garbage Project: A New Way of Looking At the Problems of Archaeology, Archaeology, Vol. 27, No. 4, (October 1974), 236-241.

Rathje, William L. et al. Discussion and Debate: Behavioural Archaeology: Four Strategies, American Anthropologist, Vol. 77, 1975, 864-868.

Rathje, William L. Modern Material Culture Studies, Advances in Archaeological Method and Theory, Vol. 2 (1979), 1-37.

Rathje, William L. The Garbage Decade: The Materialist Bias an Archaeology of US Garbage, The American Behavioral Scientist (pre-1986), Sep/Oct 1984, 9-28.

Rathje, William L. Fast Food Plastic in Landfill Garbage, American Anthropological Association: Anthropology Newsletter, Vol. 29, No. 3 March 1988, 3-4.

Rathje, William L. et al. The Archaeology of Contemporary Landfills, American Antiquity, Vol. 57, No. 3 (Jul., 1992), 437-447.

Rathje, William L. Archaeological intervention in the past, present and future tense, Archaeological Dialogues, Volume 18, Issue 02, December 2011, 176 - 180.

Rathje, William L, Shanks Michael and Witmore Christopher (editors) 2013. Archaeology in the Making: Conversations Through a Discipline, New York, Routledge.

Reschovsky, James D. and Stone, Sarah E. Market Incentives to Encourage Household W aste Recycling: Paying for What You Throw Away, Journal of Policy Analysis and Management, Vol. 13, No. 1 (Winter, 1994), 120-139. 